\title{
Developing IT-assisted Adversity Response Profile for Lectures Online during New Normal
}

\author{
Adi Satrio Ardiansyah ${ }^{1 *}$, Salsabila Naura Sari ${ }^{2}$, Nico Caesario ${ }^{3}$ \\ ${ }^{1,2,3}$ Mathematic Department, Faculty of Mathematics and Natural Sciences,Universitas Negeri Semarang, Indonesia
}

\begin{abstract}
Purpose: The purpose of this study was to develop valid and reliable IT-assisted ARP in online lectures during New Normal. IT - assisted ARP Product is the innovative learning instruments that was develop to help educators in understanding the problems experienced by students, so that they can maximize the implementation of distance education.

Methods: The research method used was Research and Development (R\&D) which was conducted on 50 students of the Department of Mathematics, Universitas Negeri Semarang. This development research consists of three stages, namely the initial investigation, the prototype phase and the assessment phase which will then be analyzed using quantitative analysis techniques.

Result: The results showed that the IT-ASSISTED ARP met the valid and reliable criteria with the rehabilitee value is very high, namely 0,98 .

Novelty: With the discover of valid and reliable ARP, educators can use it to determine the level of student ability in dealing with learning problems during the New Normal.
\end{abstract}

Keywords: Assisted ARP, Research and Development, ARP

Received January 2021 / Revised May 2021 / Accepted May 2021

This work is licensed under a Creative Commons Attribution 4.0 International License

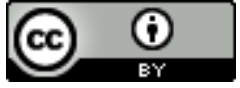

\section{INTRODUCTION}

The Covid-19 pandemic caused various problems in all activities and various sectors such as social, economic, to education. Many countries have issued an policy to temporarily close schools. In fact, as we know, the learning process in schools is the best public policy tool as an effort to increase knowledge and skills [1]. With activities at school to make children feel happy, they can interact directly with each other's friends. The school as a whole is a medium of interaction between students and teachers to improve their integrity, skills and affection between them. But now the activity called school has stopped suddenly because of the Covid-19 pandemic [2]. So, steps from all countries, including Indonesia, when temporarily closing schools are to replace them with online self-study activities at home to narrow the spread of the Corona virus. However, in Indonesia itself there are still many families who are not familiar with doing school at home [2] which can cause problems. Such as the quality of the material received to psychological problems for students who are not used to studying at home online.

The learning activities at home continued until the government implemented the new normal policy, including the new norms in the education sector. In the current new normal policy, we as a society are required to live side by side with the Covid-19 pandemic but still pay attention to all aspects of the health protocol [2]. The application of social distancing as the main factor of New Normal itself is able to create its own challenges for people in the world of education, who usually bring together teachers and students in an effort to carry out the teaching and learning process. Therefore, those who are involved in the world of education are obliged to find solutions related to how the teaching and learning process in the new normal era can keep going, without neglecting the role of the teacher as a teacher [2].

\footnotetext{
${ }^{*}$ Corresponding author.

Email addresses: adisatrio@ mail.unnes.ac.id (Satrio) salsabillanaurasari.sn@ students.unnes.ac.id (Sari) nicocaesario24@gmail.com (Caesario) DOI:10.15294/sji.v8i1.28828
} 
Distance Education is currently one of the solutions that the government can offer so that education in Indonesia continues. Distance education is education that uses one or more technologies to deliver instruction to students who are separated from the instructor and to support regular and substantive interaction between the students and the instructor synchronously or asynchronously [3]. Several online applications are used to support distance learning or online such as the zoom application, google meet, google classroom, etc. During online learning, educators are required to be creative and innovative in presenting material. Not only educators, students are also required to be able to learn actively and independently. For some countries, online learning is not a problem. According to research conducted by National University, Costa Mesa, California, USA of its three faculties, it shows that there is an increase in student involvement and satisfaction in learning and an increase in student achievement. According to a National University professor, Costa Mesa, there was an $11 \%$ increase in the mean score of students [4]. In contrast to Indonesia, which is not fully ready to use learning technology with an online system or online. The limited mastery of technology by teachers and students, limited internet access, and inadequate facilities are still problems that need attention. Even with the implementation of this system, it was found that there were students who were mentally disturbed, stressed and unable to follow the learning process properly [4].

From the problems that arise, we need a tool that can measure or know the resilience and persistence of students in facing this new normality. Adversity Response Profile (ARP) is a tool used to measure Adversity Quotient (AQ). ARP is composed of four dimensions of AQ, namely the function of control (control), origin and ownership (origin and recognition), reach and endurance (endurance) [5]. Furthermore, table 1 will explain each AQ indicator. The measurement of one's AQ can be found using the formula $\mathrm{C}+\mathrm{O}_{2}+\mathrm{R}+\mathrm{E}$ $=\mathrm{AQ}$ [5]. The greater the AQ value, the better a person is in dealing with a problem.

Adversity Quotient (AQ) is defined as the ability to overcome life's difficulties and turn every challenge into an opportunity for success. In general, the concept of AQ can be used as a framework for understanding and predicting success, which can include success in personal-social functioning (positive attitude and satisfaction) [6,7]. In line with these ideas, AQ can also be used to understand and predict academic achievement or scholastic success [6]. Understanding the importance of AQ in achieving success will encourage students to always struggle in the learning process even though they have to face various obstacles and difficulties [7]. Therefore, Stoltz classified three types of people associated with AQ, namely: Quitter (low AQ), Camper (moderate AQ), and Climber (high AQ) [8]. Quieter is a group of people who are less eager to accept life's challenges. Campers are the type of people who are passionate about problems and challenges, but they stop because of their incompetence. Meanwhile, a climber is a person who continues to fight against all kinds of things that will continue to crash, be it problems, challenges or obstacles that keep happening every day.

Various studies have been conducted to examine Adversity Quotient in education, especially in mathematics learning. Investigative studies based on demographic variables have been conducted and stated that differences in age and seniority have a significant effect on differences in gender and educational background [9]. In learning mathematics, AQ provides diversity to the fulfillment of several mathematical thinking skills such as creative thinking skills from each AQ level [10]. Furthermore, AQ studies have also been carried out from the perspective of the Al-Qur'an and Hadiths which have relevance for improving self-quality such as takhalli, tahalli, and tajalli (Zuhriah, 2021). However, some of these studies have not examined students' AQ during distance learning during the New Normal period.

This study examines the development of a valid and reliable IT-assisted ARP questionnaire so that educators can use it to measure the extent to which students are able to survive and face new norms in education. In addition, the development of the ARP questionnaire can help teachers provide the right facilities to help students deal with their difficulties.

\section{METHODS}

The development model that used to develop the IT-assisted ARP includes several stage consisting of the initial investigation phase, the prototype phase, and the assessment phase [11]. In the initial investigation phase, observation are carried out to see the problems that arise during the new normal, especially in the mathematics education. In the prototype phase, the design of research instruments including a questionnaire gird and the IT-assisted ARP. Furthermore, in the assessment phase, the IT-assisted ARP was tested on 50 students in the Department of Mathematics, Universitas Negeri Semarang. 
Data were collected through filling out a questionnaire and analyzed quantitatively in order to obtain the validity and reliability of the IT-assisted ARP product. To get the validity results, the calculation of the product moment correlation coefficient is used [12]. The results of these calculations are distributed into the $r$ test formula where the value of $r$ with 5\% significant level and $d k=n-2$, then the questionnaire item is valid. Equation (1) is the product moment correlation coefficient.

$$
r_{x y}=\frac{n \sum X Y-\left(\sum X\right)\left(\sum Y\right)}{\sqrt{\left[n \sum X^{2}-\left(\sum X\right)^{2}\right]\left[n \sum Y^{2}-\left(\sum Y\right)^{2}\right]}}
$$

In this case:

$r_{x y}=$ the correlation coefficient between variables $\mathrm{X}$ and $\mathrm{Y}$

$n=$ the number of respondents

$X=$ the number of item answers

$Y=$ the total number of items

To obtain reliability results, the Cronbach Alpha calculation is used [14]. The results of these calculations are interpreted according to the Guilford criteria as follows. Equation (2) is the Cronbach Alpha coefficient.

$$
r_{11}=\left(\frac{k}{k-1}\right)\left(1-\frac{\sum \sigma_{b^{2}}}{\sigma_{t^{2}}}\right)
$$

In this case:

$r_{11}=$ the coefficient of instrument reliability

$k=$ the number of items

$\sum \sigma_{b^{2}}=$ the amount of item variance

$\sigma_{t^{2}}=$ the total variance

Table 1 The Classification of Reliability Coefficient

\begin{tabular}{cc}
\hline Reliability Coefficient $(r)$ & Interpretation \\
\hline $0.00 \leq r \leq 0.20$ & Very Low \\
$0.20 \leq r \leq 0.40$ & Low \\
$0.40 \leq r \leq 0.60$ & Medium \\
$0.60 \leq r \leq 0.80$ & High \\
$0.80 \leq r \leq 1.00$ & Very High \\
\hline
\end{tabular}

Furthermore, valid and reliable IT-assisted ARP items will be obtained so that educators can implement them.

\section{RESULT AND DISCUSSION}

In the initial investigation phase, observations was carried out to obtain the problems faced by students during New Normal. Based on these observations, 16 problems were obtained which would then be described in the four dimensions of AQ (CO2RE) in order to obtain the grid of IT-assisted ARP. Table 2 and Table 3 respectively show the elaboration of the description for each AQ indicator and translation of the problem items for each indicator AQ. 
Table 2 Description of the Adversity Quotient Indicator

\begin{tabular}{lll}
\hline \multicolumn{2}{c}{ Indicators (AQ Dimension) } & \multicolumn{1}{c}{ Description } \\
\hline C Control & $\begin{array}{l}\text { The level of control toward the events that's caused } \\
\text { problem or students' self-control when sensing problem. }\end{array}$ \\
O Origin & The ownership of the origin of problems \\
O Ownership & The ownership toward the problem \\
$\mathrm{R} \quad$ Reach & $\begin{array}{l}\text { The students' ownership of how far the problem could } \\
\text { reach other aspects of live }\end{array}$ \\
E Endurance & $\begin{array}{l}\text { Students' perception of how long will the problems going } \\
\text { on }\end{array}$
\end{tabular}

Table 3 Grid of IT-assisted ARP during New Normal

\begin{tabular}{|c|c|c|c|c|c|}
\hline Item & Problem & Indicator & Item & Problem & Indicator \\
\hline Item_1 & Problem_1 & Control (C) & Item_33 & Problem_9 & Control (C) \\
\hline Item_2 & Problem_1 & Ownership (Ow) & Item_34 & Problem_9 & Origin (Or) \\
\hline Item_3 & Problem_1 & Reach (R) & Item_35 & Problem_9 & Reach (R) \\
\hline Item_4 & Problem_1 & Endurance (E) & Item_36 & Problem_9 & Endurance (E) \\
\hline Item_5 & Problem_2 & Control (C) & Item_37 & Problem_10 & Control (C) \\
\hline Item_6 & Problem_2 & Origin (Or) & Item_38 & Problem_10 & Origin (Or) \\
\hline Item_7 & Problem_2 & Reach (R) & Item_39 & Problem_10 & Reach (R) \\
\hline Item_8 & Problem_2 & Endurance (E) & Item_40 & Problem_10 & Endurance (E) \\
\hline Item_9 & Problem_3 & Control (C) & Item_41 & Problem_11 & Control (C) \\
\hline Item_10 & Problem_3 & Origin (Or) & Item_42 & Problem_11 & Ownership (Ow) \\
\hline Item_11 & Problem_3 & Reach (R) & Item_43 & Problem_11 & Reach $(\mathrm{R})$ \\
\hline Item_12 & Problem_3 & Endurance (E) & Item_44 & Problem_11 & Endurance (E) \\
\hline Item_13 & Problem_4 & Control (C) & Item_45 & Problem_12 & Control (C) \\
\hline Item_14 & Problem_4 & Ownership (Ow) & Item_46 & Problem_12 & Origin (Or) \\
\hline Item_15 & Problem_4 & & Item_47 & Problem_12 & Reach (R) \\
\hline Item_16 & Problem_4 & Endurance (E) & Item_48 & Problem_12 & Endurance (E) \\
\hline Item_17 & Problem_5 & Control (C) & Item_49 & Problem_13 & Control (C) \\
\hline Item_18 & Problem_5 & Origin (Or) & Item_50 & Problem_13 & Ownership (Ow) \\
\hline Item_19 & Problem_5 & Reach (R) & Item_51 & Problem_13 & Reach (R) \\
\hline Item_20 & Problem_5 & Endurance (E) & Item_52 & Problem_13 & Endurance (E) \\
\hline Item_21 & Problem_6 & Control (C) & Item_53 & Problem_14 & Control (C) \\
\hline Item_22 & Problem_6 & Ownership (Ow) & Item_54 & Problem_14 & Ownership (Ow) \\
\hline Item_23 & Problem_6 & Reach (R) & Item_55 & Problem_14 & Reach (R) \\
\hline Item_24 & Problem_6 & Endurance (E) & Item_56 & Problem_14 & Endurance (E) \\
\hline Item_25 & Problem_7 & Control (C) & Item_57 & Problem_15 & Control (C) \\
\hline Item_26 & Problem_7 & Origin (Or) & Item_58 & Problem_15 & Ownership (Ow) \\
\hline Item_27 & Problem_7 & Reach (R) & Item_59 & Problem_15 & Reach (R) \\
\hline Item_28 & Problem_7 & Endurance (E) & Item_60 & Problem_15 & Endurance (E) \\
\hline Item_29 & Problem_8 & Control (C) & Item_61 & Problem_16 & Control (C) \\
\hline Item_30 & Problem_8 & Origin (Or) & Item_62 & Problem_16 & Ownership (Ow) \\
\hline Item_31 & Problem_8 & Reach (R) & Item_63 & Problem_16 & Reach (R) \\
\hline Item_32 & Problem_8 & Endurance (E) & Item_64 & Problem_16 & Endurance (E) \\
\hline
\end{tabular}

The instrument that had been designed was then tested on the research subjects, which are 50 students of the Department of Mathematics, Universitas Negeri Semarang. The questionnaire was developed using the Google Form facility. Questionnaires are distributed via a link from Google Form to students who are undergoing the online lecture process during New Normal. After that, a quantitative analysis was carried out on the validity and reliability of the items.

The calculation of the validity analysis uses Equation (1) by the Microsoft Excel application. The results of the validity analysis showed that 10 problems consisting of 40 question items were declared valid. More complete results can be seen in Table 4. 
Table 4 Results of the Analysis of the Validity

\begin{tabular}{|c|c|c|c|c|c|}
\hline Item & $r_{x y}$ & Decision & Item & $r_{x y}$ & Decision \\
\hline Item_1 & 0.41 & Valid & Item_33 & 0.36 & Valid \\
\hline Item_2 & 0.29 & Valid & Item_34 & 0.43 & Valid \\
\hline Item_3 & 0.71 & Valid & Item_35 & 0.58 & Valid \\
\hline Item_4 & 0.62 & Valid & Item_36 & 0.45 & Valid \\
\hline Item_5 & 0.44 & Valid & Item_37 & 0.49 & Valid \\
\hline Item_6 & 0.51 & Valid & Item_38 & 0.34 & Valid \\
\hline Item_7 & 0.69 & Valid & Item_39 & 0.7 & Valid \\
\hline Item_8 & 0.66 & Valid & Item_40 & 0.77 & Valid \\
\hline Item_99 & 0.47 & Valid & Item_41 & 0.38 & Valid \\
\hline Item_10 & 0.35 & Valid & Item_42 & 0.28 & Valid \\
\hline Item_11 & 0.59 & Valid & Item_43 & 0.82 & Valid \\
\hline Item_12 & 0.56 & Valid & Item_44 & 0.7 & Valid \\
\hline Item_13 & 0.37 & Valid & Item_45 & -0.7 & Invalid \\
\hline Item_14 & 0.49 & Valid & Item_46 & 0 & Invalid \\
\hline Item_15 & 0.75 & Valid & Item_47 & 0.7 & Invalid \\
\hline Item_16 & 0.44 & Valid & Item_48 & 0.6 & Invalid \\
\hline Item_17 & 0.32 & Invalid & Item_49 & -0.5 & Invalid \\
\hline Item_18 & 0.09 & Invalid & Item_50 & 0.2 & Invalid \\
\hline Item_19 & 0.55 & Invalid & Item_51 & 0.12 & Invalid \\
\hline Item_20 & 0.58 & Invalid & Item_52 & 0.24 & Invalid \\
\hline Item_21 & 0.46 & Valid & Item_53 & 0.47 & Valid \\
\hline Item_22 & 0.39 & Valid & Item_54 & 0.31 & Valid \\
\hline Item_23 & 0.51 & Valid & Item_55 & 0.34 & Valid \\
\hline Item_24 & 0.62 & Valid & Item_56 & 0.57 & Valid \\
\hline Item_25 & 0.3 & Invalid & Item_57 & 0.5 & Invalid \\
\hline Item_26 & 0.2 & Invalid & Item_58 & 0.17 & Invalid \\
\hline Item_27 & 0.67 & Invalid & Item_59 & 0.64 & Invalid \\
\hline Item_28 & 0.6 & Invalid & Item_60 & 0.64 & Invalid \\
\hline Item_29 & 0.43 & Valid & Item_61 & 0.21 & Invalid \\
\hline Item_30 & 0.4 & Valid & Item_62 & 0.13 & Invalid \\
\hline Item_31 & 0.78 & Valid & Item_63 & 0.6 & Invalid \\
\hline Item_32 & 0.57 & Valid & Item_64 & 0.6 & Invalid \\
\hline
\end{tabular}

From these 40 items, the reliability analysis was calculated using Equation (2) by Microsoft Excel applications. The results of the reliability analysis show that the reliability value is 0.98 which means that the IT-assisted ARP is reliable with very high criteria. Furthermore, Table 5 represents the elaboration of the ten problems for each of the AQ indicators on IT-assisted ARP that are valid and reliable. This product can be used by educators to describe the ability of students to solve problems and to identify problems experienced by students in distance learning during the New Normal. 
Table 5 Description of Problems in IT-assisted ARP

\begin{tabular}{|c|c|c|c|c|c|c|}
\hline \multirow{2}{*}{ No } & \multirow{2}{*}{ Item } & \multicolumn{5}{|c|}{ Indicators } \\
\hline & & $\mathbf{C}$ & Or & Ow & $\mathbf{R}$ & $\mathbf{E}$ \\
\hline 1 & Difficult to adjust to online lectures & $\mathrm{V}$ & - & $\mathrm{V}$ & $\mathrm{V}$ & $\mathrm{V}$ \\
\hline 2 & $\begin{array}{l}\text { When there is a group assignment I feel awkward } \\
\text { to discuss with my friends because I have never } \\
\text { met before }\end{array}$ & $\mathrm{V}$ & $\mathrm{V}$ & - & $\mathrm{V}$ & $\mathrm{V}$ \\
\hline 3 & $\begin{array}{l}\text { My group friend did not do the assignment given } \\
\text { to him because he did not understand the } \\
\text { assignment given }\end{array}$ & $\mathrm{V}$ & $\mathrm{V}$ & - & $\mathrm{V}$ & $\mathrm{V}$ \\
\hline 4 & $\begin{array}{l}\text { You cannot attend online lectures via video } \\
\text { conference due to connections or bad network }\end{array}$ & $\mathrm{V}$ & - & V & $\mathrm{V}$ & $\mathrm{V}$ \\
\hline 5 & I am late for assignment & $\mathrm{V}$ & - & $\mathrm{V}$ & V & $\mathrm{V}$ \\
\hline 6 & $\begin{array}{l}\text { You are worried or afraid to go to college at the } \\
\text { new normal }\end{array}$ & $\mathrm{V}$ & $\mathrm{V}$ & - & $\mathrm{V}$ & V \\
\hline 7 & $\begin{array}{l}\text { I was late submitting the exam due to poor } \\
\text { internet connection }\end{array}$ & $\mathrm{V}$ & V & - & $\mathrm{V}$ & $\mathrm{V}$ \\
\hline 8 & $\begin{array}{l}\text { Organizational activities cannot go according to } \\
\text { plan because you have to follow health protocols } \\
\text { during the new normal }\end{array}$ & $\mathrm{V}$ & $\mathrm{V}$ & - & $\mathrm{V}$ & V \\
\hline 9 & $\begin{array}{l}\text { You fail to go to a student exchange abroad } \\
\text { because of your family's declining economic } \\
\text { condition }\end{array}$ & V & - & $\mathrm{V}$ & $\mathrm{V}$ & $\mathrm{V}$ \\
\hline 10 & $\begin{array}{l}\text { You are caught cheating during the online exam } \\
\text { as a result you do not get exam scores }\end{array}$ & V & - & $\mathrm{V}$ & $\mathrm{V}$ & V \\
\hline
\end{tabular}

A series of learning processes never let go of developing an assessment instrument. In developing a good assessment instrument, validity and reliability are necessary. Validity relates to what is measured from an instrument and how well it performs, whereas reliability is concerned with the consistency or confidence that the measuring tool controls random errors, and the two have an inverse relationship, the stronger the basis for validity, the weaker the basis for reliability (and vice versa) [14,15,16]. This shows that the research instrument needs to be developed with due regard to validity and reliability so that valid and reliable instruments will be obtained. This is the basis for the development of the IT-assisted ARP instrument, so that student AQ information can be obtained during the online lectures on New Normal period. This will make it easier for the teacher.

The AQ measuring instrument has been developed by Stoltz which considers the Control, Origin, Ownership, Reach, and Endurance indicators or more commonly known as CO2RE [17]. Several researchers have also modified the instrument for research in areas such as education, nursing, business, mental health, and so on [18,19,20,21,22]. The development of a valid and reliable adversity quotient profile to measure how to overcome the difficulties of nurses in Korea has been developed [18]. The same thing was done by Bingquan with the results of the adversity quotient scale which had good validity and reliability so that it could be used as an effective tool to measure AQ for college students [19]. Furthermore, Venkatesh \& Shivaranjani confirms how the application of AQ measurement tools and techniques that Stoltz has developed which basically helps to identify and improve individual AQ by building resilience so as to increase human capacities and capabilities, namely practical knowledge that is very grounded about human capacity [23].

In learning mathematics itself, many researchers have conducted AQ studies. The results of the literature study state that AQ has a positive impact on several mathematical thinking skills such as the ability to understand mathematics, the ability to argue mathematics, the ability to think critically, and the ability to think creatively [24,25,26,27]. AQ also has a positive effect on several affective aspects of students such as self-efficacy, motivation, locus of control, and math phobia [27,28,29,30]. Several researchers also agree that AQ can improve student achievement in learning mathematics [27,28,31,32]. It is proved that Adversity Quotient needs to be considered in learning mathematics. The problems faced by students are not only students' incomprehension and misconceptions about mathematics, but the level of stress during college and various personal and family problems color and affect the level of student resilience in facing problems. This problem is getting more complicated with the Covid-19 Pandemic and the New Normal period. So the problems presented in table 5 are very natural and related to what students are facing in online lectures 
during this New Normal. This is very suitable to be appointed in the ARP instrument as the main focus in student resilience in the implementation of online lectures during the New Normal.

\section{CONCLUSION}

Based on the above discussion, IT-assisted ARP development has been adapted to the needs of students' problems in distance education during the New Normal and fulfills the validity and reliability analysis. From 16 problems and 64 items that were developed and then tested, 10 problems and 40 items were valid. Furthermore, a reliability analysis was performed with a reliability score of 0.98 which means it meets the criteria of being reliable. These results indicate that IT-assisted ARP is appropriate to be developed so that educators identify problems that are being faced by students in distance learning during the New Normal. Some of the problems that have been generated include difficulties in adjusting to online lectures, connection disruption during learning and final test collection, worries about coming to campus during New Normal, worries about the implementation of student activities, and some problems during learning such as awkwardness during group discussions delays in submitting assignments, and cheating on exams. With the development of IT-assisted ARP with exploratory studies of student problems in distance learning during this New Normal, it is hoped that it can help educators to identify their ability to deal with problems in the learning process. Thus, educators can find the right model or approach as well as the right application platform to maximize the distance learning process during the New Normal. Problem development can also be adjusted to the level of school and the regional characteristics of each student.

\section{REFERENCES}

[1] M. J. Vavrus, “An essay review - The lingering inequality issue,” Urban Rev., vol. 11, no. 1, pp. 45-52, 1979.

[2] R. H. Syah, "Dampak Covid-19 pada Pendidikan di Indonesia: Sekolah, Keterampilan, dan Proses Pembelajaran," SALAM J. Sos. dan Budaya Syar-i, vol. 7, no. 5, 2020.

[3] A. . Rafsanjani, "Kebijakan Pendidikan Di Era New Normal," osf.io, vol. 8, no. 5, p. 55, 2019.

[4] a Fatwa, "Pemanfaatan Teknologi Pendidikan di Era New Normal," Indones. J. Instr. Technol., vol. 1, no. September, pp. 20-30, 2020.

[5] J. E. Seaman, I. E. Allen, and J. Seaman, "Grade Increase: Tracking Distance Education in the United States.," Babson Surv. Res. Gr., 2018.

[6] A. Kusnayat, N. Sumarni, A. S. Mansyur, Q. Y. Zaqiah, and U. T. Bandung, "Pengaruh Teknologi Pembelajaran Kuliah Online Di Era Covid-19 Dan Dampaknya Terhadap Mental Mahasiswa," EduTeach J. Edukasi dan Teknol. Pembelajaran, vol. 1, no. 2, pp. 153-165, 2020.

[7] R. Puwarsih, "Kemampuan Berpikir Kreatif Matematis Siswa SMP dalam Menyelesaikan Soal Pemecahan Masalah di Tinjau dari Adversity Quotient Tipe Climber," AKSIOMA J. Progr. Stud. Pendidik. Mat., vol. 8, no. 2, pp. 323-332, 2019.

[8] Espanola, "Presented in 3 rd International Conference in Education, Psychology, and Social Science ( ICEPSS ) International Research Enthusiast Society Inc . ( IRES Inc .), ” Proceeding J. eduacation, Psychol. Soc. Sci. Res., pp. 1-6, 2016.

[9] C. V. Zhi-hsien, "A Study Investigating the Influence of Demographic Variables on Adversity Quotient," J. Hum. Resour. Adult Learn., vol. 10, no. 1, pp. 22-32, 2014.

[10] A. S. Ardiansyah, I. Junaedi, and M. Asikin, "Student's Creative Thinking Skill and Belief in Mathematics in Setting Challenge Based Learning Viewed by Adversity Quotient," Unnes J. Math. Educ. Res., vol. 7, no. 1, pp. 61-70, 2018.

[11] A. Ekayanti and H. K. Nasyiithoh, "Profile of Students' Errors in Mathematical Proof Process Viewed from Adversity Quotient (AQ)," Tadris J. Kegur. dan Ilmu Tarb., vol. 3, no. 2, p. 155, 2018.

[12] H. Wijaya, "Metode Penelitian Pendidikan Teologi,” E-Modul, no. August 2013, pp. 1-8, 2013.

[13] B. Johnson and C. Larry, "Educational Research:Quantitative, Qualitative, and Mixed Approaches," Los Angeles, Calif, no. 10, p. 523, 2012.

[14] R. Heale and A. Twycross, "Validity and reliability in quantitative studies," Evid. Based. Nurs., vol. 18, no. 3, pp. 66-67, 2015.

[15] L. Fendler, "Ethical implications of validity-vs.-reliability trade-offs in educational research," Ethics Educ., vol. 11, no. 2, pp. 214-229, 2016.

[16] H. K. Mohajan, "Two Criteria for Good Measurements in Research: Validity and Reliability," Ann. Spiru Haret Univ. Econ. Ser., vol. 17, no. 4, pp. 59-82, 2017.

[17] Stoltz, "Your Adversity Quotient by Paul Stoltz, Ph.D.," J. Peak Learn., 2000.

[18] H. J. An, J. Y., Woo, H. Y., Song, J. H., \& Kim, "Validity and Reliability of Adversity Quotient 
Profile for Measuring," J. Korea Acad. Coop. Soc., vol. 15, no. 4, pp. 2285-2294, 2014.

[19] L. Bingquan, "The Compilation of the Adversity Quotient Scale for College Students," Psychol. Behav. Sci., vol. 8, no. 1, p. 9, 2019.

[20] M. C. Santos, "Assessing the Effectiveness of the Adapted Adversity Quotient Program in a Special Education School,” Res. World, vol. 3, no. 4, p. 13, 2012.

[21] L. Tigchelaar and K. E. Bekhet, "The relationship of Adversity Quotient and Personal Demographic Profile of Private Business Leaders in Egypt," Int. J. Sci. Basic anda Appl. Res., vol. 20, no. 1, pp. 403-422, 2015.

[22] C. S. N. Somaratne, L. N. A. C. Jayawardena, and B. M. K. Perera, "Impact of adversity quotient on stress levels of middle-level managers of non-governmental organisation (NGO) sector," Trop. Agric. Res., vol. 29, no. 1, p. 45, 2017.

[23] G. Venkatesh, J., \& Shivaranjani, "Adversity quotient profile: a robust assessment tool to measure human resilience.," Asian J. Res. Soc. Sci. Humanit., vol. 6, no. 6, pp. 412-426., 2016.

[24] W. Hidayat, M. S. Noto, and R. Sariningsih, "The influence of adversity quotient on students' mathematical understanding ability," J. Phys. Conf. Ser., vol. 1157, no. 3, 2019.

[25] W. Hidayat, Wahyudin, and S. Prabawanto, "The mathematical argumentation ability and adversity quotient (AQ) of pre-service mathematics teacher," J. Math. Educ., vol. 9, no. 2, pp. 239-248, 2018.

[26] W. Hidayat, Wahyudin, and S. Prabawanto, "Improving students' creative mathematical reasoning ability students through adversity quotient and argument driven inquiry learning," J. Phys. Conf. Ser., vol. 948, no. 1, 2018.

[27] B. Suryadi and T. I. Santoso, "Self-Efficacy, Adversity Quotient, and Students' Achievement in Mathematics," Int. Educ. Stud., vol. 10, no. 10, p. 12, 2017.

[28] N. Nurhayati and N. Fajrianti, "Pengaruh Adversity Quotient (AQ) dan Motivasi Berprestasi terhadap Prestasi Belajar Matematika," Form. J. Ilm. Pendidik. MIPA, vol. 3, no. 1, pp. 72-77, 2015 .

[29] S. R. S. Ahmad, "Pengaruh math phobia, self-efficacy, adversity quotient dan motivasi berprestasi terhadap prestasi belajar matematika siswa SMP," J. Ris. Pendidik. Mat., vol. 3, no. 2, p. 259, 2016.

[30] M. Nurfitriyanti, N. M. Rosa, and F. P. Nursa'adah, "Pengaruh Kemampuan Berpikir Kritis, Adversity Quotient dan Locus of Control Terhadap Prestasi Belajar Matematika," JKPM (Jurnal Kaji. Pendidik. Mat., vol. 5, no. 2, p. 263, 2020.

[31] S. U. S. Supardi U.S., "Pengaruh Adversity Qoutient terhadap Prestasi Belajar Matematika," Form. J. Ilm. Pendidik. MIPA, vol. 3, no. 1, pp. 61-71, 2015.

[32] Leonard and N. Amanah, "Pengaruh adversity quotient dan kemampuan berpikir kritis terhadap prestasi belajar matematika,” Perspekt. Ilmu Pendidik., vol. 28, no. 1, pp. 55-64, 2014. 